This item was submitted to Loughborough's Research Repository by the author.

Items in Figshare are protected by copyright, with all rights reserved, unless otherwise indicated.

\title{
The direct electrochemistry of ferritin compared with the direct electrochemistry of nanoparticulate hydrous ferric oxide
}

PLEASE CITE THE PUBLISHED VERSION

PUBLISHER

(c) The Royal Society of Chemistry and the Centre National de la Recherche Scientifique

\section{VERSION}

AM (Accepted Manuscript)

\section{LICENCE}

CC BY-NC-ND 4.0

\section{REPOSITORY RECORD}

Marken, Frank, Dimple Patel, Claire E. Madden, Roy C. Millward, and Stephen Fletcher. 2019. "The Direct Electrochemistry of Ferritin Compared with the Direct Electrochemistry of Nanoparticulate Hydrous Ferric Oxide". figshare. https://hdl.handle.net/2134/6064. 
This item was submitted to Loughborough's Institutional Repository (https://dspace.lboro.ac.uk/) by the author and is made available under the following Creative Commons Licence conditions.

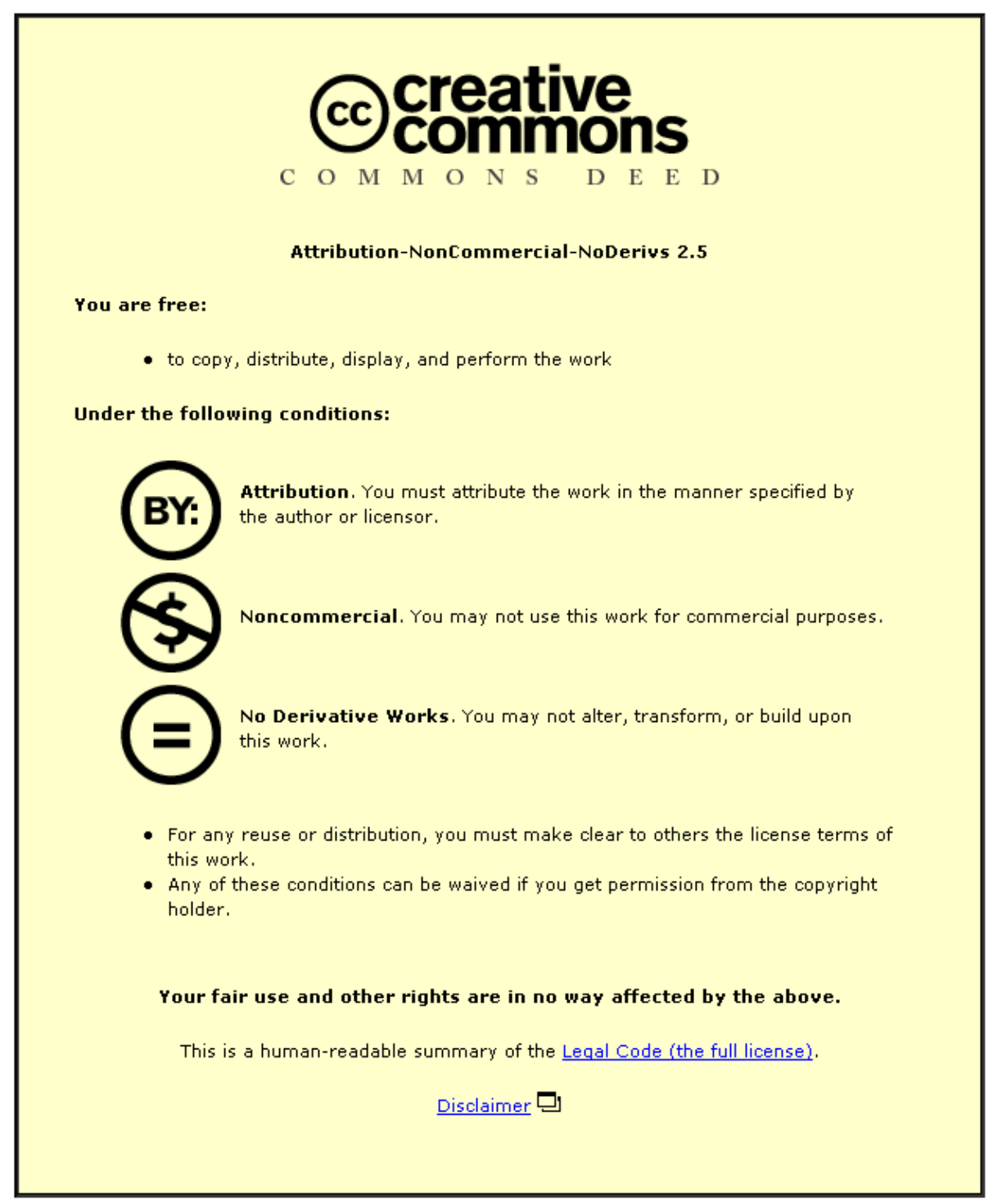

For the full text of this licence, please go to: http://creativecommons.org/licenses/by-nc-nd/2.5/ 
F. Marken, D. Patel, C. E. Madden, R. C. Millward, and S. Fletcher, New Journal of Chemistry, 26, 259-263 (2002)

Submitted 13 SEPT $01 \quad$ Accepted 12 NOV $01 \quad$ Published 18 JAN 02

Digital Object Identifier is DOI: 10.1039/b108500j

The institutional repository is http://hdl.handle.net/2134/6064

The original publication is at http://www.rsc.org/ej/NJ/2002/b108500j.pdf

Copyright is (c) The Royal Society of Chemistry and the Centre National de la Recherche

Scientifique 2002

\title{
The direct electrochemistry of ferritin compared with the direct electrochemistry of nanoparticulate hydrous ferric oxide
}

Frank Marken, Dimple Patel, Claire E. Madden, Roy C. Millward, and Stephen Fletcher

\author{
Department of Chemistry, \\ Loughborough University, \\ Ashby Road, Loughborough, \\ Leicestershire LE11 3TU, UK
}

Tel. 01509222561 Fax 01509223925

Email Stephen.Fletcher@Lboro.ac.uk

\section{Keywords}

Ferritin • iron oxide $\bullet$ nanoparticle $\bullet$ adsorption $\bullet$ voltammetry $\bullet$ hydrogen peroxide $\bullet$ electrocatalysis. 


\section{ABSTRACT}

Horse spleen ferritin is a naturally occurring iron storage protein, consisting of a protein shell encapsulating a hydrous ferric oxide core about $8 \mathrm{~nm}$ in diameter. It is known from prior work that the protein can be adsorbed onto the surface of tin-doped indium oxide (ITO) electrodes, where it undergoes voltammetric reduction at about $-0.6 \mathrm{~V}$ vs Ag/AgCl. This is accompanied by dissolution of Fe(II) through channels in the protein shell. In the present work, it is demonstrated that a pre-wave at about -0.4 $\mathrm{V}$ vs $\mathrm{Ag} / \mathrm{AgCl}$ is due to the reduction of $\mathrm{FePO}_{4}$ also present inside the protein shell.

In order to prove that the pre-wave was due to the reduction of $\mathrm{FePO}_{4}$, it was first necessary to prepare $8 \mathrm{~nm}$ diameter hydrous ferric oxide nanoparticles without protein shells, adsorb them onto ITO electrodes, and then study their electrochemistry. Having achieved that, it was then necessary to establish that their behaviour was analogous to that of ferritin. This was achieved in several ways, but principally by noting that the same electrochemical reduction reactions occurred at negative potentials, accompanied by the dissolution of Fe(II). Finally, by switching to aqueous phosphate buffer, the pre-wave could be unambiguously identified as the reduction of $\mathrm{FePO}_{4}$ present as a thin layer on the hydrous ferric oxide nanoparticle surfaces.

Although the bare and protein-coated hydrous ferric oxide nanoparticles were found to behave identically toward electrochemical reduction, they nevertheless reacted very differently towards $\mathrm{H}_{2} \mathrm{O}_{2}$. The bare nanoparticles acted as potent electrocatalysts for both the oxidation and the reduction of $\mathrm{H}_{2} \mathrm{O}_{2}$, whereas the horse spleen ferritin had a much lesser effect. It seems likely therefore that the protein shell in ferritin blocks the formation of key intermediates in hydrogen peroxide decomposition.

\section{INTRODUCTION}

Ferritins, which are type of metalloprotein, play an important role in iron metabolism in animals, plants, fungi and bacteria [1]. They have the capacity to remove ferrous ions $\left(\mathrm{Fe}^{2+}\right.$ ions) from solution, oxidize them, and store the resulting ferric ions $\left(\mathrm{Fe}^{3+}\right.$ ions) in their interior $[2,3]$.

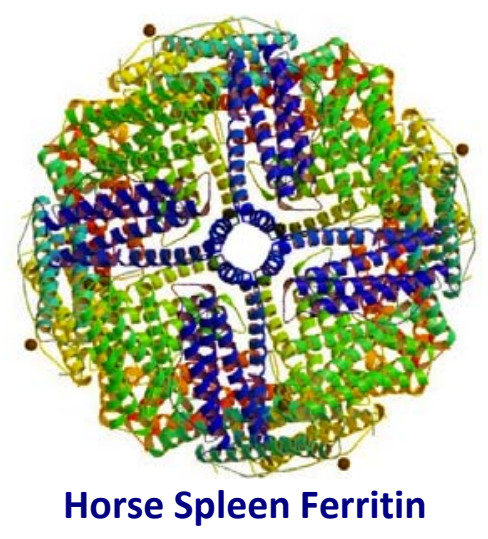

[Image courtesy of the Protein Data Bank. Data derived from Granier, T., Gallois, B., Dautant, A., Langlois d`Estaintot, B., Precigoux, G., Acta Crystallogr., Sect. D 53: 580-587 (1997).] 
All ferritins are composed of 24 protein sub-units arranged in the 432 point group [1]. That is, all ferritins share the same tertiary structure, with four 3-fold axes of symmetry arranged along the major diagonals of an imaginary cube, and three 4-fold axes of symmetry passing between opposite faces of the same cube. Their molecular weight is circa $460 \mathrm{kDa}$. When assembled, the 24 protein sub-units form a hollow, roughly spherical, shell with an outside diameter of 10-12.5 nm (depending upon species), and an inside diameter of $8.0 \mathrm{~nm}$. In mammals, two types of protein subunit have been identified [4]. The first is called the heavy $(\mathrm{H})$ subunit and has a molecular weight of $21 \mathrm{kDa}$. This contains a ferroxidase site where the oxidation of $\mathrm{Fe}^{2+}$ likely takes place. The second subunit is called the light $(\mathrm{L})$ subunit and has a molecular weight of $19 \mathrm{kDa}$. Regardless of sub-unit composition, iron is always stored as an inorganic compound: predominantly hydrous ferric oxide (HFO) in animals, and possibly as a hydrous ferric phosphate (HFP) in bacteria.

Around the central cavity, the 24 protein subunits pack together in a seamless manner, except at the six 4-fold junctions and eight 3-fold junctions where multiple subunits meet. At those junctions special channels exist. The 4-fold channels, which are lined with leucine residues, are hydrophobic. By contrast, the 3-fold channels, which are lined with glutamate and aspartate residues, are hydrophilic. The details of the $\mathrm{Fe}^{2+}$ ion transport and oxidation processes inside ferritin are not settled, but it seems likely that soluble $\mathrm{Fe}^{2+}$ ions enter the protein shell through the hydrophilic 3-fold channels, and are oxidized to insoluble $\mathrm{Fe}^{3+}$ ions in the protein interior [3]. (Non-complexed $\mathrm{Fe}^{3+}$ ions are of course immobile at physiological $\mathrm{pH}$, due to their insolubility.)

Little is known about the crystal structure of the hydrous ferric oxide (HFO) that is formed in the protein interior, because the particle size is too small to yield well resolved x-ray diffractograms. In the literature the crystal structure of the particles is often said to be that of ferrihydrite, but confirmatory data are lacking [5]. The situation is complicated by the fact that all hydrous ferric oxides are built up from $\mathrm{Fe}(\mathrm{O}, \mathrm{OH})_{6}$ octahedra, and differ only in the ways that the octahedra are linked via corners, edges or faces. This makes them difficult to distinguish — and also makes them prone to forming mixed intergrowths. In addition, Fe atoms at surfaces or defects tend to be octahedrally coordinated to $\mathrm{H}_{2} \mathrm{O}$ ligands, which creates compositional uncertainty. For large particles this might not be a significant problem, but for $8 \mathrm{~nm}$ particles fully one third of the iron atoms are surface atoms.

Besides the above difficulties, it is known that phosphate anions also play a complicating role [6]. It is a commonplace observation of mineral chemistry that phosphate anions have a strong affinity for ferric oxide below $\mathrm{pH}$ 8.5. Moreover, inside ferritin, the HFO particle must contain less than $4500 \mathrm{Fe}(\mathrm{O}, \mathrm{OH})_{6}$ octahedra in order to fit inside the $8 \mathrm{~nm}$ cavity. This means that the ratio of phosphate to iron for mammalian ferritin can reach $10 \%$, with phosphate possibly adsorbed on the surface of the HFO. In bacteria the ratio of phosphate to iron can reach $50 \%$, suggesting even more complex chemistry. An important question is therefore - what is the role of phosphate in the redox chemistry of ferritin?

To answer this question, we here compare the electrochemical behaviour of two types of hydrous ferric oxide nanoparticle, protein-coated and 'bare', in phosphate buffer solutions. This is made possible by the fact that both types of nanoparticle readily adsorb onto tin-doped indium oxide (ITO) electrode surfaces. The adsorption of 
protein-coated HFO (ferritin) on ITO has been reported previously by Zapiens and coworkers $[7,8,9,10]$. So far as we are aware, however, the adsorption of bare HFO on ITO is new. As we shall see, the comparison is fascinating. We find that almost identical voltammograms are observed in both cases, despite the presence of the protein shell surrounding the HFO in the ferritin core. How electrons tunnel through this shell and into the core is a mystery. However, it appears that the protein shell remains intact, because the rate of oxidation of hydrogen peroxide remains much less on adsorbed ferritin than on adsorbed HFO.

\section{EXPERIMENTAL}

\section{Reagents}

Chemical reagents $\mathrm{FeCl}_{3}, \mathrm{FeCl}_{2} \cdot 4 \mathrm{H}_{2} \mathrm{O}$ (Avocado), $\mathrm{HNO}_{3}$ (Aldrich), $\mathrm{K}_{2} \mathrm{HPO}_{4}, \mathrm{KH}_{2} \mathrm{PO}_{4}$ (BDH), and $\mathrm{H}_{2} \mathrm{O}_{2}$ (27.5 wt\%, Aldrich) were obtained commercially and used without further purification. Demineralised and filtered water was taken from an Elga water purification system (Elga, High Wycombe, Bucks) and had a resistivity of not less than $18 \mathrm{MOhm} \mathrm{cm}$. Phosphate buffer solutions were prepared as mixtures of $\mathrm{K}_{2} \mathrm{HPO}_{4}$ and $\mathrm{KH}_{2} \mathrm{PO}_{4}$, and the $\mathrm{pH}$ adjusted by addition of $\mathrm{KOH}$.

Hydrous ferric oxide (HFO) was prepared by Sorum's method [11,12]. A solution of $0.02 \mathrm{M} \mathrm{FeCl}_{3}$ in $50 \mathrm{~cm}^{3}$ water was added slowly to $450 \mathrm{~cm}^{3}$ boiling water (2 drops per second). Upon completion, the mixture was allowed to cool to room temperature and then dialyzed against $\mathrm{HClO}_{4}(\mathrm{pH} 3.5)$ for 48 hours. The resulting deep orange sol of HFO was decanted and used immediately. Transmission electron microscopy (TEM) images revealed uniform nanoparticles of HFO about 8-10 nm diameter (Fig. 1).

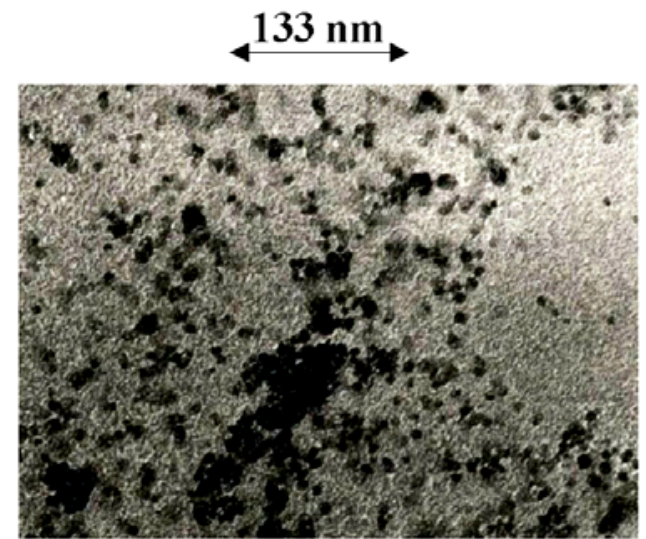

FIGURE 1. TEM image of hydrous ferric oxide (HFO) nanoparticles.

Some care was needed to ensure that the sol did not recrystallize to goethite, $\alpha$ $\mathrm{FeOOH}$, or hematite, $\alpha-\mathrm{Fe}_{2} \mathrm{O}_{3}$ [13]. Goethite, the most common iron oxide in soils, is well known to form by ferrihydrite dissolution and reprecipitation, while hematite forms from ferrihydrite by internal aggregation and rearrangement [14]. Recrystallization rates are affected by many factors, but most particularly $\mathrm{pH}$ and temperature. Schwertmann and Murad [15] reported that half conversion of ferrihydrite to goethite at $25^{\circ} \mathrm{C}$ at $\mathrm{pH} 12$ occurred in $<4 \mathrm{~d}$, while half conversion to hematite and goethite at $\mathrm{pH} 7$ took $>100 \mathrm{~d}$. Heating also hastens ferrihydrite 
recrystallization. For these reasons we carried out all experiments within a few days of HFO preparation, at room temperature. It should also be noted that the $\mathrm{pK}_{\mathrm{a}}$ 's of phosphoric acid are 2.12, 7.21, and 12.32, so between $\mathrm{pH} 2-7$ the $\mathrm{H}_{2} \mathrm{PO}_{4}{ }^{1-}$ ion is the predominant ion, while between $\mathrm{pH}$ 7-12 the $\mathrm{HPO}_{4}{ }^{2-}$ ion is the predominant ion.

Horse spleen ferritin (Type I, $69 \mathrm{mg} \mathrm{cm}^{-3}$ in $0.15 \mathrm{M} \mathrm{NaCl}$, Sigma) was purified prior to use by size exclusion chromatography through a column $(25 \mathrm{~mm} \times 100 \mathrm{~mm}$ ) packed and equilibrated with Sephadex-100 (Sigma) in $0.1 \mathrm{M}$ or $1.0 \mathrm{M}$ phosphate buffer solution ( $\mathrm{pH} 7$ ). [Sephadex is a trade name for cross-linked dextran gel, which separates water-soluble proteins on the basis of their molecular size.]

\section{Apparatus}

For voltammetric studies an Autolab PGSTAT 30 potentiostat system (EcoChemie, Netherlands) was employed with a Pt mesh counter electrode, a BAS Ag/AgCl (3 M $\mathrm{NaCl}$ ) reference electrode, and a conical glass cell. Tin-doped indium oxide electrodes (Image Optics Components Ltd., Basildon, Essex, UK) were $7 \mathrm{~mm} \times 10 \mathrm{~mm}$ in area. Transmission electron microscopy (TEM) images were obtained on a Jeol JEM100CX system operating at $100 \mathrm{kV}$. Experiments were conducted after deoxygenating with high purity argon (BOC) for at least 15 minutes prior to experiments. The temperature was $22 \pm 2{ }^{\circ} \mathrm{C}$.

\section{RESULTS AND DISCUSSION}

\section{Voltammetry of the Fe(II/III) Redox Couple in Phosphate Buffer Solution}

Fig. 2(a-c) shows cyclic voltammograms of $1 \mathrm{mM} \mathrm{Fe}^{2+}$ dissolved in $0.1 \mathrm{M}$ phosphate buffer solution at $\mathrm{pH}$ 7. The shapes of the voltammograms are those expected for the reaction

$\mathrm{Fe}^{2+}(\mathrm{aq})+\mathrm{HPO}_{4}^{2-}(\mathrm{aq}) \rightarrow \mathrm{FePO}_{4}($ solid $)+\mathrm{H}^{+}(\mathrm{aq})+\mathrm{e}^{-}$

The nucleation of $\mathrm{FePO}_{4}$ (solid) is visible as the rapid rise in current on the positivegoing scans. Such voltammograms are consistent with the fact that although $\mathrm{Fe}^{2+}$ is soluble in phosphate buffer, $\mathrm{Fe}^{3+}$ is not. This difference in solubility is particularly apparent when $\mathrm{Fe}^{2+}$ solutions are exposed to air: the rapid oxidation of $\mathrm{Fe}^{2+}$ to $\mathrm{Fe}^{3+}$ at $\mathrm{pH} 7$ causes a white precipitate of $\mathrm{FePO}_{4}$ to form within a few seconds. (The latter is $x$-ray amorphous, so may also be hydrated.)

Inspection of the potential scale in Fig. 2(a-c) reveals that, in the presence of phosphate, the equilibrium potential of the Fe(II/III) couple is shifted by ca. $0.6 \mathrm{~V}$ to negative values when compared to the Fe(II/III) system in aqueous hydrochloric acid [16]. The same shift is evident in the peak potentials for oxidation and reduction, which are $E_{\mathrm{p}}{ }^{0 \mathrm{x}}=-0.27 \mathrm{~V}$ vs $\mathrm{Ag} / \mathrm{AgCl}$ and $E_{\mathrm{p}}{ }^{\text {red }}=-0.55 \mathrm{~V}$ vs $\mathrm{Ag} / \mathrm{AgCl}$, respectively. This indicates that the negatively-charged phosphate ions are stabilizing $\mathrm{Fe}^{3+}$ more than $\mathrm{Fe}^{2+}$. 


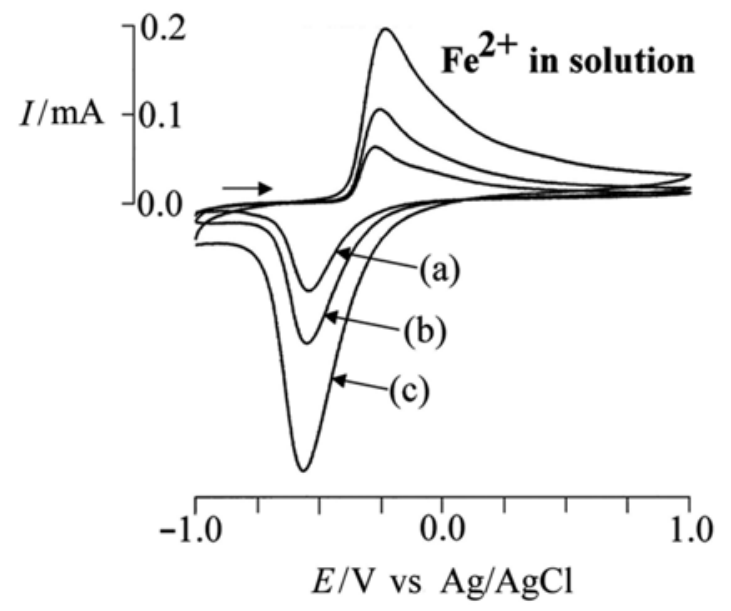

FIGURE 2(a-c). Cyclic voltammograms of $1 \mathrm{mM} \mathrm{Fe}^{2+}$ at a $10 \mathrm{~mm} \times 7 \mathrm{~mm} \mathrm{ITO}$ electrode immersed in $0.1 \mathrm{M}$ phosphate buffer solution ( $\mathrm{pH} 7$ ), at scan rates (a) 0.1 $\mathrm{V} / \mathrm{s}$, (b) $0.2 \mathrm{~V} / \mathrm{s}$, and (c) $0.5 \mathrm{~V} / \mathrm{s}$.

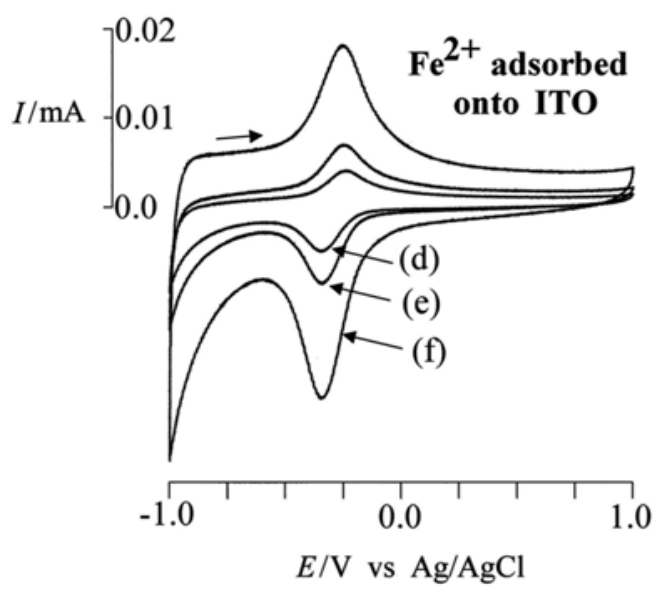

FIGURE 2(d-f). Cyclic voltammograms of $\mathrm{Fe}^{2+}$ adsorbed on a $10 \mathrm{~mm} \times 7 \mathrm{~mm}$ ITO electrode (adsorbed initially as $\mathrm{Fe}^{3+}$ from a solution of $40 \mathrm{mM} \mathrm{FeCl}_{3}$ in $0.1 \mathrm{M} \mathrm{HNO}_{3}$ ) in $0.1 \mathrm{M}$ phosphate buffer solution (pH 7), at scan rates (d) $0.1 \mathrm{~V} / \mathrm{s}$, (e) $0.2 \mathrm{~V} / \mathrm{s}$, and (f) $0.5 \mathrm{~V} / \mathrm{s}$.

Fig. 2(d-f) illustrates what happens when iron is removed from the electrolyte solution. The ITO electrode retains a small but detectable voltammetric response centred at $-0.23 \mathrm{~V}$ vs $\mathrm{Ag} / \mathrm{AgCl}$. Since the voltammogram is almost symmetric, and the peak heights increase linearly with scan rate, this response can be due only to the redox cycling of a strongly adsorbed monolayer of iron ions. In confirmatory experiments, we found that the same monolayer could be formed from $40 \mathrm{mM} \mathrm{Fe}^{3+}$ in $0.1 \mathrm{M} \mathrm{HNO}_{3}$, and that it remained intact even after exhaustive reduction at $-1.0 \mathrm{~V} v \mathrm{~s}$ $\mathrm{Ag} / \mathrm{AgCl}$ in $0.1 \mathrm{M}$ phosphate buffer solution, where soluble $\mathrm{Fe}^{2+}$ might otherwise have been expected to form. 
Having considered the voltammetry of soluble Fe(II/III), we now consider the voltammetry of insoluble HFO nanoparticles. To obtain this, it was first necessary to dip ITO electrodes in the deep orange sol of hydrous ferric oxide prepared by Sorum's method ( $2 \mathrm{mM}$ based on Fe). After rinsing with copious amounts of de-ionized water, it was found that the electrode surface was coated with an adherent layer of HFO nanoparticles. This coated electrode was sufficiently robust to be transferred to an electrochemical cell containing $0.1 \mathrm{M}$ phosphate buffer solution. Fig. 3 shows some typical results. On the first voltammetric cycle, two reduction peaks are seen having $E_{\mathrm{p}}^{\mathrm{I}}=-0.33 \mathrm{~V}$ vs $\mathrm{Ag} / \mathrm{AgCl}$ and $E_{\mathrm{p}}^{\mathrm{II}}=-0.51 \mathrm{~V}$ vs $\mathrm{Ag} / \mathrm{AgCl}$. On the second voltammetric cycle, only one reduction peak is seen, having $E_{\mathrm{p}}{ }^{\mathrm{I}}=-0.35 \mathrm{~V}$ vs $\mathrm{Ag} / \mathrm{AgCl}$. We attribute Peak I to the reduction of $\mathrm{Fe}^{3+}$ in the $\mathrm{FePO}_{4}$, and we attribute Peak II to the reduction of $\mathrm{Fe}^{3+}$ in the HFO nanoparticles.

$\mathrm{HFO}($ solid $)+\mathrm{e}^{-} \rightarrow \mathrm{Fe}^{2+}(\mathrm{aq})+\mathrm{OH}^{-}+\mathrm{H}_{2} \mathrm{O}$

It is clear that Peak I' is the re-nucleation of $\mathrm{FePO}_{4}$ on the electrode surface.

Quite different results are obtained in the presence of $10 \mathrm{mM}$ EDTA (Fig. 3d). On the first voltammetric cycle only one reduction peak is seen having $E_{\mathrm{p}}^{\mathrm{II}}=-0.50 \mathrm{~V}$ vs $\mathrm{Ag} / \mathrm{AgCl}$. This is doubtless due to the reduction of HFO and the formation of an Fe(II) EDTA complex. This is so soluble that on the second voltammetric cycle no reactant is left on the electrode.

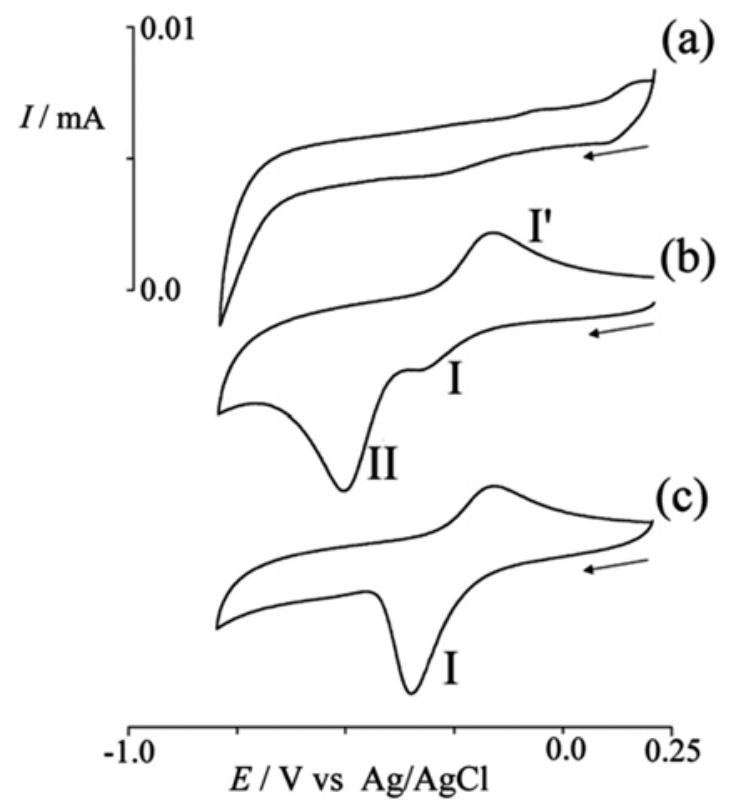

FIGURE 3. Cyclic voltammograms of bare HFO adsorbed on a $10 \mathrm{~mm} \times 7 \mathrm{~mm}$ ITO electrode, at a scan rate of $0.1 \mathrm{~V} / \mathrm{s}$. The solution was $0.1 \mathrm{M}$ phosphate buffer, $\mathrm{pH} 7$. (a) Background, (b) first cycle, (c) second cycle. 
(d)

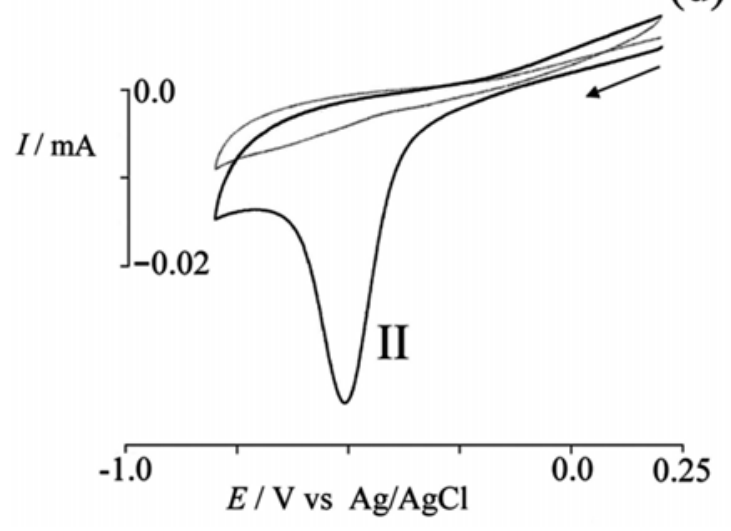

FIGURE 3 (cont.) Cyclic voltammograms of bare HFO adsorbed on a $10 \mathrm{~mm} \times 7 \mathrm{~mm}$ ITO electrode, at a scan rate of $0.1 \mathrm{~V} / \mathrm{s}$. The solution was $0.1 \mathrm{M}$ phosphate buffer, $\mathrm{pH}$ 7. (d) First and second cycle in the presence of $10 \mathrm{mM}$ EDTA.

\section{Voltammetry of Horse Spleen Ferritin in Phosphate Buffer Solution}

Horse spleen ferritin readily adsorbs onto ITO electrodes and is known to give voltammetric responses associated with the reduction of its HFO core. Voltammograms of ferritin adsorbed from a $0.1 \mathrm{M}$ phosphate buffer solution (pH 7) are shown in Fig. 4.

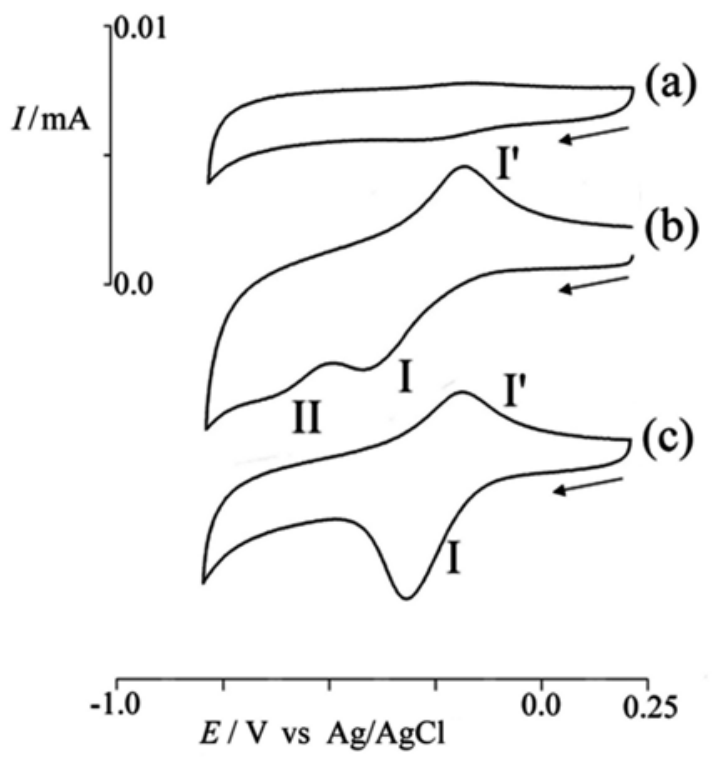

FIGURE 4. Cyclic voltammograms of ferritin adsorbed on a $10 \mathrm{~mm} \times 7 \mathrm{~mm}$ ITO electrode, at a scan rate of $0.1 \mathrm{~V} / \mathrm{s}$. The solution was $0.1 \mathrm{M}$ phosphate buffer, $\mathrm{pH} 7$. (a) Background, (b) first cycle, (c) second cycle. 
On the first voltammetric cycle, two reduction peaks are seen having $E_{\mathrm{p}}{ }^{\mathrm{I}}=-0.41 \mathrm{~V} v \mathrm{~s}$ $\mathrm{Ag} / \mathrm{AgCl}$ and $E_{\mathrm{p}}{ }^{\mathrm{II}}=-0.64 \mathrm{~V}$ vs $\mathrm{Ag} / \mathrm{AgCl}$. On the second voltammetric cycle only one reduction peak is seen, having $E_{\mathrm{p}}{ }^{\mathrm{I}}=-0.32 \mathrm{~V}$ vs $\mathrm{Ag} / \mathrm{AgCl}$. The similarity of these voltammetric features with those of bare HFO (Fig. 3) is remarkable. There seems little doubt that we are observing the same electrochemistry as in the bare HFO case, despite the presence of the protein shell in the ferritin case. We are therefore seeing the reduction of $\mathrm{FePO}_{4}$ within the ferritin core.

Parallel results to the bare HFO case are observed when EDTA is added. A welldefined reduction peak with $E_{\mathrm{p}}{ }^{\mathrm{II}}=-0.52 \mathrm{~V}$ vs $\mathrm{Ag} / \mathrm{AgCl}$ is observed on the first voltammetric cycle, which disappears on the second voltammetric cycle. Presumably an $\mathrm{Fe}$ (II) EDTA complex is forming here too, but whether this escapes the protein shell is not known. Wherever the complex finally resides, the redox reaction "switches off".

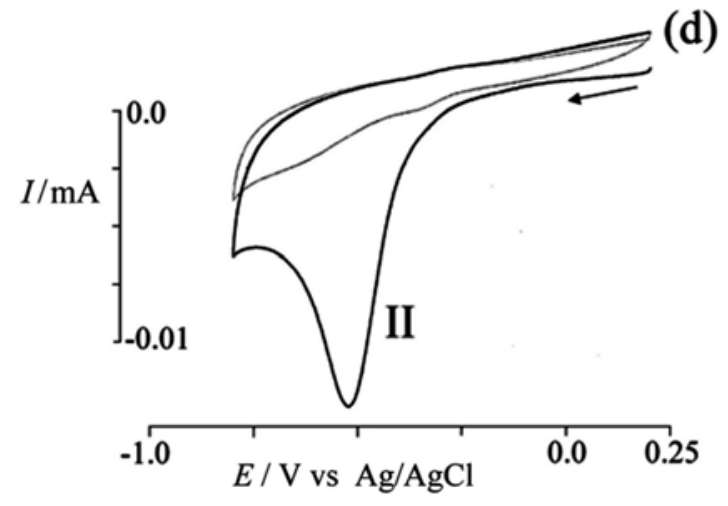

FIGURE 4 (cont.) Cyclic voltammograms of ferritin adsorbed on a $10 \mathrm{~mm} \times 7 \mathrm{~mm}$ ITO electrode, at a scan rate of $0.1 \mathrm{~V} / \mathrm{s}$. The solution was $0.1 \mathrm{M}$ phosphate buffer, $\mathrm{pH} 7$. (d) First and second cycle in the presence of $10 \mathrm{mM}$ EDTA.

\section{The Overall Reaction Scheme}

Fig. 5 shows a cartoon of the overall reaction scheme during the first voltammetric cycle, in the absence of EDTA. Ferric phosphate reduces first, and hydrous ferric oxide (HFO) reduces second. Upon re-oxidation, ferric phosphate nucleates on the electrode surface.

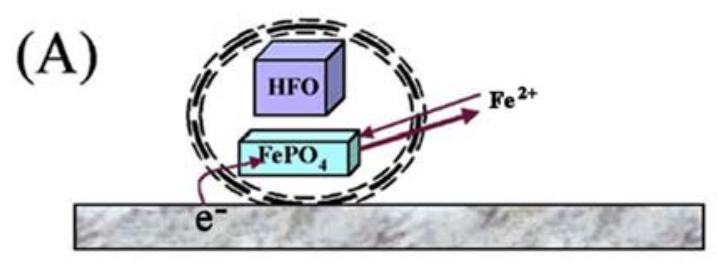



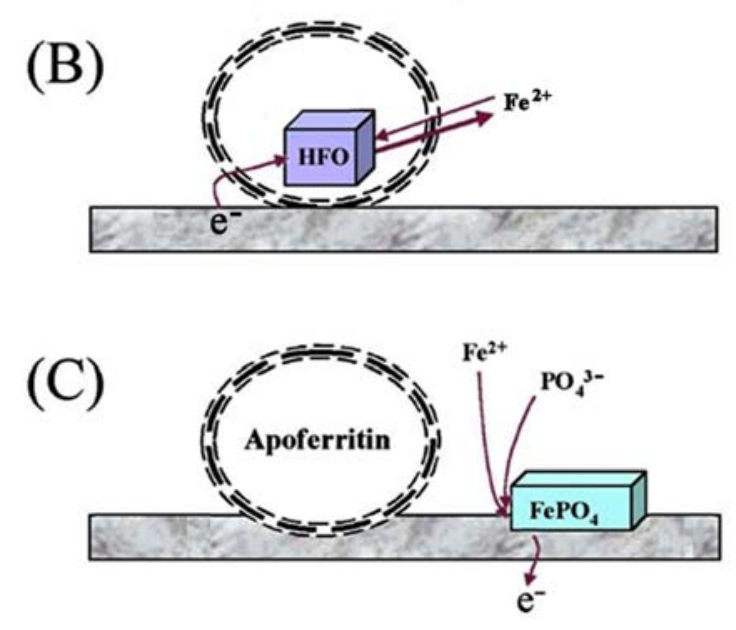

FIGURE 5. The overall reaction scheme of the electrochemical reduction of ferritin. (A) Reductive dissolution of ferric phosphate, (B) reductive dissolution of hydrous ferric oxide, and (C) re-oxidation leading to ferric phosphate nucleation on the electrode surface. Note: Apoferritin is ferritin that is devoid of iron.

\section{Voltammetry in the Presence of Hydrogen Peroxide $\mathrm{H}_{2} \mathrm{O}_{2}$}

The striking similarity between the voltammograms of bare HFO and ferritin prompts the question - does the protein shell of ferritin survive the adsorption process on ITO surfaces? To answer this question, it is sufficient to summarise our experiments on a new phenomenon that we discovered during the course of this work, namely the catalysis of hydrogen peroxide reduction by adsorbed HFO.

Fig. 6 shows a series of voltammograms on different electrode surfaces, for the oxidation and reduction of $3 \mathrm{mM}$ hydrogen peroxide in aqueous $0.1 \mathrm{M}$ phosphate buffer solution. Curve 6(a) is the background current in the absence of $\mathrm{H}_{2} \mathrm{O}_{2}$, curve 6(b) is the normal voltammogram of $\mathrm{H}_{2} \mathrm{O}_{2}$, curve 6(c) shows the effect of preadsorbing ferritin on the electrode surface, and curve 6(d) shows the effect of preadsorbing HFO on the electrode surface. It is obvious by inspection that a large electrocatalytic effect is caused by the pre-adsorbed HFO, whereas no such effect is associated with the pre-adsorbed ferritin. It is likely that the catalysis of the $\mathrm{H}_{2} \mathrm{O}_{2}$ oxidation process involves coordination to Fe(III) sites. However, more experimental work will be required before the mechanistic details can be resolved.

Based on the above results, we can be reasonably confident that the protein shell in ferritin remains intact during the adsorption process, because it is blocking the formation of key intermediates during hydrogen peroxide decomposition. 

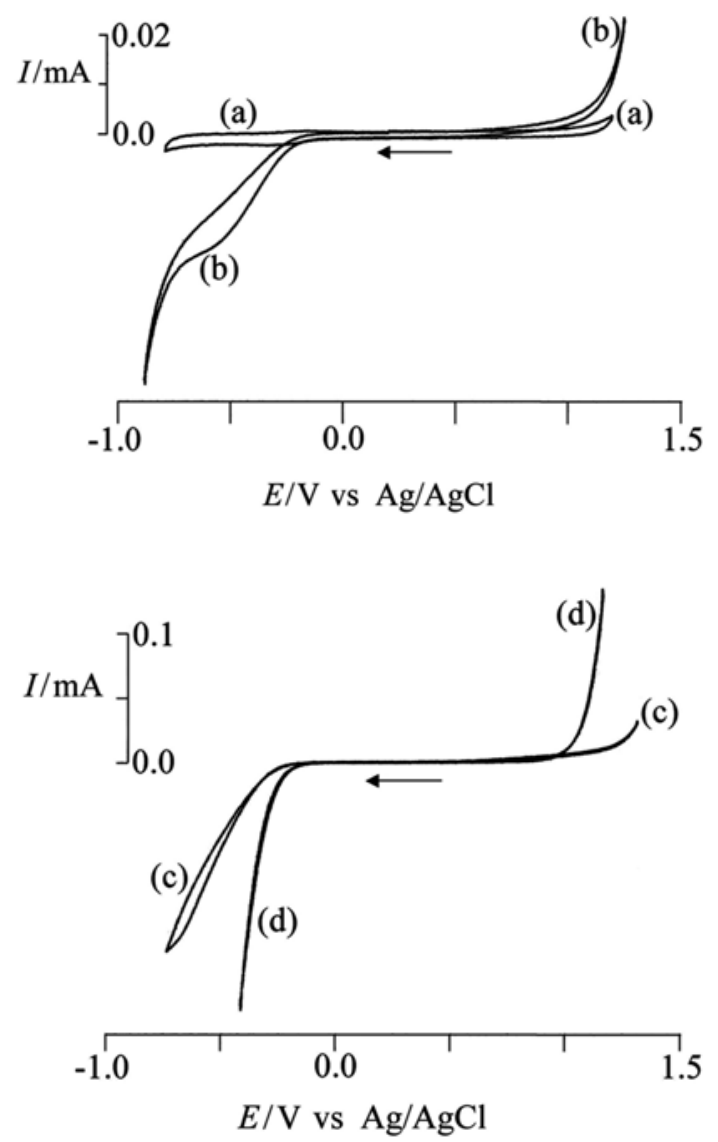

FIGURE 6. Cyclic voltammograms of hydrogen peroxide at a $10 \mathrm{~mm} \times 7 \mathrm{~mm}$ ITO electrode. In each case the solution was $3 \mathrm{mM} \mathrm{H}_{2} \mathrm{O}_{2}$ in $0.1 \mathrm{M}$ phosphate buffer solution at $\mathrm{pH}$ 7. Scan rate $0.1 \mathrm{~V} / \mathrm{s}$. (a) ITO without $\mathrm{H}_{2} \mathrm{O}_{2}$, (b) ITO with $\mathrm{H}_{2} \mathrm{O}_{2}$, (c) ITO with $\mathrm{H}_{2} \mathrm{O}_{2}$ and ferritin, (d) ITO with $\mathrm{H}_{2} \mathrm{O}_{2}$ and HFO.

\section{CONCLUSIONS}

It has been shown that both horse spleen ferritin and hydrous ferric oxide (HFO) nanoparticles can be adsorbed on the surface of ITO electrodes, and their direct electrochemistry observed. Remarkably, they exhibit very similar voltammetric characteristics, which means that (i) the voltammetric detection of $\mathrm{FePO}_{4}$ inside ferritin is possible, and that (ii) the HFO core of ferritin is somehow electrically connected to the electrode surface. The pathway of this connection is unknown. A possible alternative explanation, namely that the protein shell of ferritin is lost upon adsorption, can be discounted because the protein shell continues to block the redox electrochemistry of hydrogen peroxide.

\section{ACKNOWLEDGEMENT}

F.M. thanks the Royal Society for the award of a University Research Fellowship. 


\section{REFERENCES}

[1] For a review see S. Mann, J. Webb, R. J. P. Williams, Biomineralisation, VCH, Weinheim, 1989.

[2] E. C. Theil, Adv. Inorg. Biochem., 1983, 5, 1.

[3] E. C. Theil, Ann. Rev. Biochem., 1987, 56, 289.

[4] See for example S. Levi, S. J. Yewdall, P. M. Harrison, P. Santambrogio, A. Cozzi, E. Rovida, A. Albertini, P. Arosio, Biochem. J., 1992, 288, 591.

[5] See for example J. M. Cowley, D. E. Janney, R. C. Gerkin, P. R. Buseck, J. Struct. Biol. 2000, 131, 210.

[6] Y. G. Cheng, N. D. Chasteen, Biochem., 1991, 30, 2947.

[7] T. D. Martin, S. A. Monheit, R. J. Niichel, S. C. Peterson, C. H. Campbell, D. C. Zapien, J. Electroanal. Chem, 1997, 420, 279.

[8] D. C. Zapien, M. A. Johnson, J.Electroanal.Chem., 2000, 494, 114.

[9] R. J. Cherry, A. J. Bjornsen, D. C. Zapien, Langmuir, 1998, 14, 1971.

[10] M.-S. Pyon, R. J. Cherry, A. J. Bjornsen, D.C. Zapien, Langmuir, 1999, 15, 7040.

[11] C. H. Sorum, J. Am. Chem. Soc., 1928, 50, 1263.

[12] P. Mulvaney, R. Cooper, F. Grieser, D. Meisel, Langmuir, 1988, 4, 1206.

[13] U. Schwertmann, W. Fischer, Zeits. Anorg. Allg. Chem., 1966, 346, 137.

[14] U. Schwertmann, R. M. Cornell. Iron Oxides in the Laboratory: Preparation and Characterization. Verlag Chemie, Weinheim, 1991.

[15] U. Schwertmann, E. Murad, Clays Clay Mineral. 1983, 31, 277.

[16] A. J. Bard, L. R. Faulkner, Electrochemical Methods: Fundamentals and Applications, Wiley, New York, 2000, p.810.

8888888888888888888888888888888888888888888888888888888888888888888 